\title{
Dutch delay decision on nuclear expansion...
}

Holland is unlikely to build any more nuclear power plants until 1990. Discussion of an expansion programme -and in particular problems of uranium enrichment and waste disposal-is now into its fifth year. According to a recent government decision, the debate is to continue over the next two years and it looks as though a decision on the future of nuclear energy in the country will not be made before 1982 .

The limitations of Holland nuclear energy - the country has two plants, both small (477 MW and $56 \mathrm{MW}$ )were recognised by the previous government in 1974. Three more plants, each of $1,000 \mathrm{MW}$, were called for, but plans for them were shelved two years later.
The urgency of the energy problem was highlighted by Mr Van Aardenne, Minister for Economic Affairs, in a recent letter to Parliament. Almost all the country's $14,500 \mathrm{MW}$ energy capacity would have to be renewed by the end of the 1980s. By then, natural gas, which at present fuels three quarters of the country's power stations, would have to be reserved for domestic use rather than generation of electricity. But shifting totally to coal-fired power plants would mean consuming 14 million tons of coal a year by 1995 (compared with only a million tons now), rising to 23 million tons a year by the end of the century. Consequently, a quick decision was needed on the possible contribution of nuclear energy, the Minister said.
Disposal of nuclear waste will figure prominently in the two years of public debate now ahead. It was this issue that caused postponement in 1976 of the earlier plans to build three more nuclear power stations. Moreover, a guarantee of acceptable means of waste disposal and storage before building new plants was also part of the election platform of the new government elected last year.

The government is to speed up its research on waste disposal. Five sites for storage salt domes have already been provisionally picked but research is being hampered by the refusal of the local authorities involved to cooperate. Even so, a team of government experts has said the first storage mine could not be ready until 1995 .

\section{... but let safeguards slip on Brazil deal}

THE Dutch government has agreed to start delivering enriched uranium to Brazil around 1981-without complete international safeguards. Initially, the Dutch had wanted an assurance that international control of plutonium after reprocessing would be in force at the time of the first delivery. Now, however, in a decision in parliament in June, they have agreed to start delivering the uranium if safeguards are likely to be in force by the time reprocessing starts, probably in 1986.

The Brazil saga started in October 1976 when the former government of Social Democrats, Christian Democrats and a few radicals decided to expand Urenco's ultra-centrifuge uranium enrichment plant at Almelo. Its capacity was to be increased from the present 200 tonnes to 1,200 tonnes per year. The expansion is only partly based on the Brazilian order for uranium; but this in turn is coupled with the 10 billion DM transaction for nuclear technology between West Germany and Brazil.

Brazil's order includes eight 1,200 MW nuclear power plants, a reprocessing plant, and enrichment technology based on the German 'nozzle process'. The nozzle process is not yet operating commercially, so Brazil has to begin by importing enriched uranium. German participation in Urenco meant that a delivery from Almelo seemed possible.

As with all international nuclear sales there had to be agreement on safeguards against weapons-buiding, and in February 1976 Germany, Brazil, and the IAEA reached a trilateral agreement.

But the agreement threw the Netherlands into a political storm. Brazil appeared to have given no safeguards or guarantees for the import of enriched uranium in 1981 , but only agreed to accept a plutonium storage regime under IAEA control in about 1986 when the first uranium will be reprocessed. And if Brazil would agree then, why could it not agree now?

The Dutch parliament repeatedly postponed a decision on what Holland should do. The radicals were threatening to break up the government coalition over the issue. A final decision on a plutonium storage regime and IAEA safeguards covering the whole nuclear cycle (so-called 'full-scope' safeguards) was expected in about March 1976, but was still pending at the end of last year. The former Dutch foreign minister, Mr Van der Stoel, declared later that the problem of IAEA inviolability and right of say on the movement and storage of plutonium was still in discussion with the Brazilians when the government changed in December 1977.

The new coalition of Christian Democrats and Conservatives presented Parliament with an agreement between the Urenco partners and Brazil, similar to the February 1976 agreement. But at the end of January 1978 parliament adopted a motion for a more definite agreement. It approved the expansion of the Almelo plant and also decided that no uranium from Almelo could be exported to non-NPT countries unless strict safeguards were agreed in advance. A motion, carried by an overwhelming majority in the Lower House, stated that an export licence for uranium could be granted only if a plutonium storage regime under the control of the International Atomic Energy Agency (IAEA) was in force or an ad hoc agreement on the storage of plutonium was reached between Holland and Brazil. The government agreed that it would respect and carry out Parliament's decision.

The affair received a new impulse. Discussions and negotiations with Germany and Britain started up again; but these failed.

At the European summit conference in Copenhagen in the Spring, Chancellor Schmidt had no scheduled meeting with the Dutch prime minister Van Agt. The Dutch foreign minister, Van der Klaauw, was refused a meeting with his Brazilian colleague, who was in Bonn, and the Germans threatened to build their own enrichment plant across the Dutch-German border to deliver the uranium to Brazil when the tripartite treaty ends in 1981. The Dutch could then drop out if they still refused to export the uranium on the basis of the agreement made last January. The Germans were said to prefer to continue without the Dutch - who were said to weigh moral and political considerations more heavily than economic ones.

However, some German politicians realised it would be a political error if Germany were not to extend the Urenco agreement beyond 1981. The United States favoured the Netherlands remaining in Urenco, but thought that the safeguards should be 'full-scope', covering the whole nuclear cycle, rather than just covering the storage of plutonium.

Apart from the political implications there have also been doubts about the commercial future of Urenco. The original plan was to expand the Almelo and Capenhurst plants to a total joint 
capacity of 5,000 tonnes by 1985 . Now, however, a capacity of only about 2,000 tonnes per year is foreseen for 1984. Although the Brazilian order is only $10 \%$ of the uranium now on order, it will be sold at a profitable price, which is more than can be said of the previous German orders. At the end of March 1978 it became known that Dutch banks were excluded from financing the Brazilian uranium order because only the German and British governments are providing the guarantees.

In the first six months of this year, the matter was discussed extensively four times in the Dutch parliament. In March 30,000 people, some from Germany, demonstrated in Almelo. Two weeks later, 50,000 people from 28 eastern-bloc and western countries took part in a demonstration in Amsterdam against the neutron bomb and nuclear energy. And at the end of June The Hague was the scene of a similar demonstration.

In the meantime it came into the open that the IAEA, at least, had been in favour of a plutonium storage regime. Although such a regime cannot be set up for a few years, an ad hoc regime in Brazil on the basis of an available blue print seemed feasible. What was needed to put the scheme into practice was the political will of the countries concerned, said IAEA deputy secretary general Fischer on Dutch television. A proposal for such a regime would be judged positively by the IAEA board on which 35 countries are represented. However, so far the Urenco partners have not requested an international storage scheme for plutonium.

In an international safeguards system, there would be regional depots for plutonium but probably not in Brazil. In an ad hoc regime with Urenco such a depot could be in Brazil. Brazil will therefore be against a world storage regime.

The whole affair came to an end with the government's decision at the end of June. The motion adopted by the majority of parliamentarians in January required that a storage regime be established before the first delivery of uranium takes place. The final agreement, which states that a storage regime must be available when re- processing starts, is less stringent in its requirements.

Now the only reservation is that there should be sufficient certainty, at the moment of delivery of the first uranium, that before reprocessing starts an agreement would be reached on a storage regime. However, parliament may find difficulty in judging the likelihood of such an agreement being reached, leaving the government fairly free to manoeuvre.

What has happened is what Germany and Britain wanted, say the opponents, who also tried other moves to avoid this agreement. The social democrats presented a bill to regulate the future export of all nuclear material, as in the United States; if accepted the bill would also include the deliveries to Brazil.

The net result of the negotiations is that the opposition feel that the whole affair has been a blow to democracy and to attempts to create a proliferation proof society. "We move from coresponsibility to complicity", the spokesman of the opposition (social democrats) said in parliament

Casper Schuuring

\section{US plans to ban the use of nitrites in food}

THE US government is planning to introduce a gradual ban on the use of nitrites in food, following the results of studies carried out at the Massachusetts Institute of Technology indicating a "strong suggestion" that nitrites are carcinogenic.

Steps have already been taken to reduce the use of nitrites as preservatives, particularly in cured meat such as bacon and ham, because of evidence that, when cooked and eaten, they can combine with other chemicals to cause carcinogenic nitrosamines..

The latest study, however, which was conducted by Dr Paul Newberne of MIT, is the first to link nitrites directly with cancer. In the study, $13 \%$ of rats fed sodium nitrites developed tumours of the lymph system, compared to only $8 \%$ of those not fed nitrite.

The US Department of Agriculture and the Food and Drug Administration have called the results "statistically significant", and said in a statement last week that the study "leads us to the concern that nitrites may increase the incidence of human cancer."

Under current legislation, both agencies have a range of powers to take action against any food additive suspected of being carcinogenic. However in this instance the government is refraining from acting precipitously partly because of the embarrassment caused by its attempts to ban the use of saccharin, a move on which Congress has since imposed an 18-month moratorium.

An additional factor is that the use of nitrites considerably cuts down the danger of botulism poisoning from preserved meats, and permits greater freedom in shipping and storage. "We must weigh the risk associated with nitrites added to food against the health risk of not adding it" the two agencies said in their statement.

Because of the public health angle, the federal government is considering ways of introducing a gradual ban on the use of nitrites in circumstances where protection against botulism toxics is important, and where alternative safety techniques need to be developed and implemented. There is likely to be a quicker ban on products

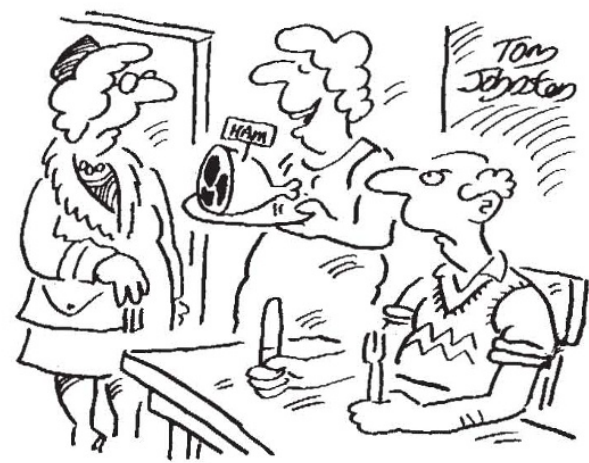

"If I don't get him with cancer, I'll get him with botulism!" that are always cooked thoroughly before they are eaten, since this generally eliminates the chances of botulism poisoning.

In addition to banning nitrites, the government is also proposing to ban the addition of nitrates to processed foods, a move which could, for example, have an impact on the import of cheeses.

The economic impact of a ban on nitrites could be even bigger than that of the proposed ban on saccharin. According to the American Meat Institute, a nitrite ban could "all but destroy the US hog industry, since nearly $70 \%$ of our pork ends up in processed meat products-mostly cured meats." Annual consumption of such products in the US is currently about $\$ 12.5$ billion.

In the light of such a potential impact, measures to forestall a ban on nitrites were introduced into the US Congress last Thursday by Representative James Martin of North Carolina and Representative William Wampler of Virginia.

The two Congressmen are seeking to block any ban until at least three months after the government completes its current investigations into other suspected carcinogens, including saccharin. The issue is not likely to be debated this year, but could become a hot topic when the new Congress meets after the fall elections.

David Dickson 